\title{
INSTITUTIONAL SUPPORT FROM CREDIT UNION OF TORAJA CHURCH SYNOD FOR CONGREGATION ECONOMIC EMPOWERMENT
}

\author{
By \\ I Wayan Ruspendi Junaedi ${ }^{1}$, I Wayan Damayana², Dermawan Waruwu ${ }^{3}$, I Made Sumartana ${ }^{4}$, \\ Donald Samuel Slamet Santosa ${ }^{5}$ \\ 1,2,3 Universitas Dhyana Pura, Indonesia \\ ${ }^{4}$ Universitas Ngurah Rai, Indonesia \\ ${ }^{5}$ Universitas Presiden, Indonesia \\ Email: dsamuel@president.ac.id
}

\begin{abstract}
Article Info
Article history:

Received Nov 9, 2021

Revised Dec 20, 2021

Accepted Jan 11, 2022

\section{Keywords:}

Institutional support,

Credit union,

Toraja church,

Congregation economic,

Credit facility

ABSTRACT

The article was aimed to analyze the institutional support given by the Credit Union of Toraja Church Synod for congregation economic empowerment and then to construct the model of this institutional support. Research typology in this article was research and development. The development intended by this research was referred to Developmental Model 4D (Define, Design, Develop, and Dissemination). The outputs of this research were the factual model outlining institutional support for congregation economic empowerment, the hypothetical model expected to improve factual model, and the validated final model. Research approach involved quantitative and qualitative approaches. The results of research showed that the Credit Union of Toraja Church Synod had offered institutional supports including credit facility to be accessed by the congregation. The new model illustrated the participation of the congregation in the decision making process of the Credit Union and also the training and counseling services provided by the Credit Union for the congregation in matters of taking loan for business development. The new model was proved to be effective in empowering the congregation economic.
\end{abstract}

This is an open access article under the CC BY-SA license.

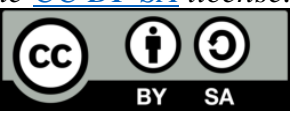

\section{Corresponding Author:}

Donald Samuel Slamet Santosa,

Universitas Presiden,

Jababeka Education Park, Ki Hajar Dewantara Road, Bekasi Regency 17530, Indonesia.

Email: dsamuel@president.ac.id

\section{INTRODUCTION}

The Bible said that the church is institutionalized with many functions (tasks or roles) and the prominent amongst the functions are koinonia, martyria, and diakonia (Homrighausen \& Enklaar, 2008). Koinonia is the function of maintaining church community to improve the congregation faith. Martyria is the function of giving testimony or conducting biblical evangelism to the non-Christians. Diakonia is the dedication of the church to help people in solving their problems in education, social, economic and other life aspects.

Compared to the other functions, diakonia is the most general function. Diakonia can be applied to not only common people but also church members or congregation. Diakonia touches many life aspects of the congregation but this article will concern only the economic aspect.

Economic scholars consider "money" as an instrument to facilitate an exchange activity. Under diakonia perspective, money shall be used wisely (Noordegraaf, 2004). In other words, money must not be the idol of the congregation.

Diakonia perspective on money derives from many sources. The most popular source is a metaphor of talent explained in Matius 25:14-30. Those verses said that humans, or the congregation in this article, were blessed by the God with a knowledge regarding how to manage their wealth (assets). When humans successfully did manage their wealth, then humans must express their gratitude for the bless or the talent given to them by the God. The wrath of the God would be handed down to those who decide to not use the talent entrusted by the God to them. 
In respect to the statement above, economic is one of life aspects that needs to be kept in watch by the church. Economic supports have been offered by the church to help the congregation to develop their economic wealth, especially financial assets. The supports are relevant to the function of diakonia.

Economic empowerment is done through various approaches. According to Suhu (2020), economic empowerment can be realized through economic programs. Other opinion was given by Alwi (2020) who said that community approach is the most precise way to implement people-based economic empowerment. Many approaches can still be used as long as the final goal shall be oriented toward the empowerment of people economic. However, the final outcome intended by empowerment is not the stronger economic power but the the better living standard, which is indicated by the improvement of economic standing.

Specific institutions are founded to implement economic empowerment. Santoso (2021) described that the real sector was once empowered through the establishment of syariah financial service delivered by the Cooperative BMT. This arrangement has positioned the Cooperative BMT with an assignment for economic empowerment. The Cooperative BMT is basically a financial cooperative that applies shariah principles to its delivery of services.

Financial cooperative is a business unit or a legal entity that acts in the form of cooperative. The main goal of a cooperative is always to make its members prosperous (Sattar, 2017). The worldwide cooperatives are established based on a German model of cooperative named Raiffeisen (Sitio, Tamba, 2001).

Congregation economic empowerment through cooperative institution is chosen by the church to make the congregation prosperous. In this situation, the cooperative institution will work under the auspices of the church. Diakonia is the church function that will handle the administration of this cooperative.

The adoption of cooperative institution for the church congregation is possible only if the congregation are registered into the cooperative membership. Therefore, the church cooperative will act to improve the welfare (prosperity) of the church congregation. The operational principles of the cooperative is also used by the church cooperative which thus the church cooperative is founded from, by and for the church congregation.

Referring to the statement above, the cooperative is used by the church to implement the function of diakonia to improve the welfare of the congregation. In one point, the cooperative may relieve the church from some parts of its administrative tasks (or the tasks have been handled effectively and efficiently). On the other hand, the cooperative can help the church to bring the impact of biblical evangelism closer to the congregation.

Structurally, the church cooperative may stand under the administration of local church, prime church, or synod. The administrative coverage of the church cooperative can determine the level of membership or the size of congregation to be served. The wider administrative coverage is associated with the more congregation that can be registered into the cooperative membership. Conversely, the narrower administrative coverage leads to the fewer membership.

One of the church cooperatives with wide administrative coverage in Indonesia is Toraja Church Cooperative. The management of this Cooperative stands under the auspices of Toraja Church Synod which allows the Cooperative to not only have wide coverage area of service but also to reach out all members of the Toraja Church congregation. The work of the Toraja Church Cooperative is focused on saving and loan because the Cooperative is attempting to give the congregation with an access to financial sources. Through the presence of the Cooperative, there is an expectation that the economic standing of the Toraja Church congregation will be improved and empowered.

However, this idealism does not correspond to the reality. Some of the congregation members had been interviewed and the minutes of the interview showed that not all congregation members knew that there is a cooperative institution in their church. Some others already knew the church cooperative but showing hesitance to participate in the saving and loan activities. Surprisingly, the congregation still use other financial institutions, including the commercial banks, because those institutions charge lower interest rate than the church cooperative.

Other problem in the Toraja Church Cooperative is related with the suboptimal function of the cooperative as financial institution because the work of the cooperative is overlapping with the function of diakonia. Surely, the diakonia must respect the interest of the church in regard of empowering the congregation economic.

All these problems need to be solved immediately. Innovative solution to these problems would be strategic. The objective of this research is to analyze the institutional support from the Toraja Church Cooperative for the economic empowerment of the congregation. The model of this research is a description of actions taken by the cooperative. Later, this model is called factual model. Both strength and weakness of the factual model are analyzed. The result of analysis on factual model will be used as the material to formulate a developmental model. This developmental model is the model of institutional support given by Toraja Church Synod for the economic empowerment of the congregation. Briefly, this becomes the background of research title, which is, "Institutional Support from Credit Union of Toraja Church Synod for Congregation Economic Empowerment”. 
International Journal of Social Science (IJSS)

Vol.1 Issue.5 February 2022, pp: 589-594

ISSN: 2798-3463 (Printed) | 2798-4079 (Online)

DOI: https://doi.org/10.53625/ijss.v1i5.1299

\section{RESEARCH METHOD}

The type of this research is research and development which is carried out qualitative approach. The development is elaborated based on Developmental Model 4D (Define, Design, Develop, Dissemination).

This research begins with the collection of data regarding the services delivered by the Toraja Church Cooperative. The type of the data is qualitative which are obtained through interview and Focus Group Discussion. The informants include the leaders of the synod, the managers of the Cooperative, and the members of the congregation. The collected data are triangulated based on source and technique. Data analysis is done with Miles and Hubberman's technique. All these processes make up the stage "Define" in Model 4D.

After constructing the factual model regarding the services delivered by the Toraja Church Cooperative, the process continues to the formulation of developmental model. This process analyzes the strength and weakness of the factual model and the result of the analysis is used as material for creating a new model called hypothetic model. This stage marks the second D in Model 4D, which is, "Design".

Hypothetic model is put into validation process done by relevant experts and practitioners. The validation is an assessment given by filling out the instrument of model validation. This instrument comprises several closed statements arranged at Likert Scale from 1 to 5. Thirty (30) assessors gave their assessment on hypothetic model. The data of their assessment were then processed to obtain the mean score. Hypothesis test was conducted against this mean score at error rate of 0.05 with score 3 as good category. The operation of hypothesis test was using one sample t-test facilitated by software of SPSS 25. This stage represents the third D, which is, "Develop". In accordance with the inputs from the assessors, the model is then revised to become the final model.

If the model is surely completed, then the model is ready for dissemination. This stage denotes the last $\mathrm{D}$, which is ,"Dissemination". Indeed, the dissemination is realized through the publication of the model in the journal in the form of publication article.

\section{RESULTS AND DISCUSSION}

Three models were obtained in this research. First model is factual model, a model that has been used by the Toraja Church Cooperative. Second model is hypothetical model, which is a factual model with development to minimize the weaknessess of the factual model. Final model is actually the hypothetical model that has been validated by experts and practitioners. Each model will be explained in different paragraphs.

The Toraja Church Cooperative offers various services. This Cooperative is owned by Toraja Church Synod. The members comprise synod leaders, priests, council members, and congregation members of Toraja Church. The focus of the Cooperative is on saving and loan.

Principally, the mechanism of saving and loan and the control by Toraja Church Synod have put Toraja Church Cooperative to be called as Credit Union of Toraja Church Synod. Due to its Credit Union status, this church-based credit union shall implement the work mechanism and the functionality of credit union in general. Supervisors and caretakers are selected from the members. Also, Annual Membership Deliberation must be held once a year.

Strategic decisions are often made after examining the results of Annual Membership Deliberation. These decisions are about the interest rate of saving and loan, the election of supervisors and caretakers, the agreement for major purchase, the allotment of residual income (Sisa Hasil Usaha), and other important things.

The membership is only given to the customers of the Synod Credit Union. All members of the congregation can apply for the membership. Therefore, all members of Toraja Church congregation can be the customers of the Synod Credit Union. This arrangement enables the congregation to save their fund and also to take loan to get a fund. The individuals outside Toraja Church are not allowed to get membership.

The work mechanism of the credit union is similar to that of any other financial institutions. The credit union receives fund from the customers and then channelizes this fund to other customers who need most in the form of loan. The customers who take loan will act as borrowers and must pay the loan principal with interest fee. From this moment, the interest fee paid by the borrowers will be contributed to the customers who save their fund in the credit union. This benefit must be cut for a certain proportion to be the profit of the fund keeper.

After collecting profits, the credit union distributes the profits to its members in the form of residual income (Sisa Hasil Usaha). This income can be different across the members depending on the contribution of the members. Those who have large proportion of saving will get more residual income than those with minor saving.

When the customers are unable to pay the loan installments, the credit union begins the collection. This collection can be verbal or non-verbal, and sometimes, fine sanction can be given to the default customers who fail to pay arrears or other liabilities.

Journal homepage: https://bajangjournal.com/index.php/IJSS 
Furthermore, after analyzing the factual model, the weakness of work mechanism in the Credit Union of Toraja Church Synod was found. A deep investigation was carried out to the result of analysis, which showed that the Synod Credit Union is still unable to give the expected impact on the welfare of its members.

Some customers of the Synod Credit Union do not feel prosperous after getting the membership. These customers are those who take loan but then fail to pay installments for some reasons. The customers who take loan for business or other agendas are often vulnerable to a default. When those customers suffer loss, their liability affects money circulation in the Synod Credit Union. In one side, the default customers must face the potential loss, while on the other side, these customers must cope with collection invoice and fine sanction that need to be paid immediately. Such pressure put heavy psychological burdens on them, which force the default customers to feel less prosperous.

This weakness needs to be solved. The work orientation must be reset by returning to the main goal of the cooperative in general, which is, to make the members prosperous. Dealing with default issue, any cooperatives must not only act as the instrument to channelize the fund from the saver to the borrower. The improvement can be targeted to the customer service, the organization, and also the innovative capacity (Isa, Hartawan, 2017).

Showing a sense of humanity to the members needs to be considered by by the Credit Union of Toraja Church Synod as a requirement. Building close relationship with the members is also important because the organizational structure of the Synod Credit Union is created from and owned by the members.

One relevant thing that the Synod Credit Union can do for the members is by giving supports to the work or business of its members. This support can be given in the form of traning and counseling for the members who have business.

This support is called institutional support which is considered important to help the Synod Credit Union to improve the prosperity of its members. Training and counseling need to be given to support the business development, which also prevent the members from suffering loss and bankruptcy. When the business is profitable, the members will have capability to pay the loan. If this situation occurs, then the financial circulation of the Synod Credit Union will run well and the prosperity of the members may improve.

Any materials used in the training and counseling must be easily understood by the members in order to ensure that the expected goal of the activity is achieved. Topics that can be offered in the training and counseling activities are business planning, financial bookkeeping, marketing optimization, and business development strategy.

The trainer and counselor are selected from the membership. The members who become trainer and counselor for other members are those who have relevant capability and competence. Although the principle of mutual assistance is still used, the trainer and counselor are deserved to be given a proper compensation for their help in building managerial professionalism. All these expectations are rendered as the elements that make up the hypothetical model.

Afterwards, the hypothetical model is tested by a team of assessors to estimate the value of the model, which in the context of this research, the value is in the form of descriptive statistic value. The following two tables present the descriptive statistic values of the model and the results of hypothesis test.

Table 1. Descriptive Statistic Values

Descriptive Statistics

\begin{tabular}{cccccc}
\hline & $\mathrm{N}$ & Minimum & Maximum & Mean & Std. Deviation \\
Score & 30 & 2.60 & 4.20 & 3.4733 & .41848 \\
\hline Valid N (listwise) & 30 & \multicolumn{5}{c}{} \\
\hline
\end{tabular}

Table 2. 2 Results of One Sample T-Test

One-Sample Test

\begin{tabular}{ccccccc}
\hline & \multicolumn{9}{c}{ Test Value $=3$} \\
\cline { 5 - 7 } & & & & & \multicolumn{2}{c}{$\begin{array}{c}\text { 95\% Confidence Interval of the } \\
\text { Difference }\end{array}$} \\
\cline { 5 - 7 } & $\mathrm{t}$ & $\mathrm{df}$ & Sig. (2-tailed) & Mean Difference & Lower & Upper \\
\hline Score & 6.195 & 29 & .000 & .47333 & .3171 & .6296 \\
\hline
\end{tabular}

In Table 1, the score given by the assessor team for the hypothetical model is varying in the range from 2.6 to 4.2. The mean score for the hypothetical model is 3.47 with standard deviation of 0.41 . The score of 3.47 is compatible to the good category that requires Score 3. One sample t-test shows that value differential of 0.47 is 
International Journal of Social Science (IJSS)

Vol.1 Issue.5 February 2022, pp: 589-594

ISSN: 2798-3463 (Printed) | 2798-4079 (Online)

DOI: https://doi.org/10.53625/ijss.v1i5.1299

considered significant at error rate of 0.000 . This result signifies that this model receives good assessment from the assessors (evaluators) and this assessment makes the model become reliable for the implementation.

The implementation of the new model, which is considered better than the previous model, shall improve the work of the cooperative, or the Credit Union of Toraja Church Synod in this research. The prominent effect is usually related to member satisfaction (Khuswati, Relita, 2019) due to the improvement of service. Other improvement is also found in the operational performance of the cooperative, as previously said by Utami and Pramesti (2020).

Although the Synod Credit Union remains optimistic that the model is already good, several innovations can still be applied for helping the institution to develop and to achieve its goal to empower the economic welfare of the congregation. The innovations include information system (Rahma, 2018), website (Romadhon, Desmulyati, 2019), and credit application through cellular phone (Rumetna, Lina, and Santoso, 2020).

Experts or members with relevant capability or competence shall not act only as trainer or counselor for another members but also give their energy to develop the cooperative institution, as stated by Dianto and Amsari (2021). Results of training and counseling must be registered for its patent right to protect intellectual property, as explained by Sugiyanto, Putri and Kartolo (2021).

\section{CONCLUSION}

The model that is capable to strengthen the institutional capacity of the Credit Union of Toraja Church Synod is the model that can empower the economic welfare of the congregation. This model requires the participation of congregation members in the decision making process and the training and counseling for the members regarding the business development. This model is proved to be effective based on the assessment of experts and practitioners. By these statements, the Credit Union of Toraja Church Synod is suggested to use the proposed model to ensure that the economic empowerment of the congregation can be achieved.

\section{REFERENCES}

[1] Alwi, M. M.,"Mosque-Based People Economic Empowerment During Covid-19 Pandemic,"Al-Hikmah, Journal of Preaching Science and Community Development, vol.18 (1), 2020.

[2] Dianto, D., Amsari, S.,"The Fostering of Cooperatives in the Muhammadiyah Branch of Sukasari Village to Build People Economic After Covid-19 Pandemic,"Journal of Community Service,vol.3(2), 2021.

[3] Homrighausen, E. G., Enklaar, I. H., "Christianity Education,"2008.

[4] Isa, IGT., Hartawan, GP.,"The Design of Web-Based Application for the Credit Union (Case Study of Mitra Setia Cooperative),"Scientific Journal of Economic Science, vol.5(10), 2017.

[5] Khuswati, E., Relita, D.T.,"The Effect of Service Quality on Member Satisfaction at the Credit Union of Bhakti Lestari in Sungai Tebelian District,"Journal of Economic Education,vol.4(2), 2019.

[6] Noordegraaf, A., "Church Diakonia Orientation: Theology in Reformation Perspective,"2004.

[7] Rahma, F., "The Design of Information System for Group-Based Shariah Financing in the Credit Union,"National Journal of Technology and Information System,vol.4(1), 2018.

[8] Romadhon, SS., Desmulyati., "The Design of Credit Information System Website Using Framework Codeiginter for the Cooperative of Bumi Sejahtera Jakarta,"Journal of Information System, Informatics, and Computing,vol.3(1), 2019.

[9] Rumetna, MS., Lina, TN., Santoso, AB., "The Design of Credit Application Using the Method of Research and Development,"Journal of Industrial, Machinery, Electronic Engineerings and Computer Science,vol.11(1), 2020.

[10] Santoso, I. R., "People Economic Empowerment (Empowering Real Sector Through the Cooperative of BMT Shariah Financial Service)," 2021.

[11] Sattar, "Teaching Book of Cooperative Economics," 2017.

[12] Sitio, A., Tamba, H., "The Cooperatives: Theory and Practice," 2001.

[13] Sugiyanto, S., Putri, A., Kartolo, R., "Intellectual Property Potential for The Empowerment of SMEs and Cooperatives in South Tangerang City,"Proceeding of Universitas Pamulang,vol. 1 (1), 2019.

[14] Suhu, B. L., "Economic Empowerment Program for Fisher Community in the Coastal Area of Tidore Kepulauan City (Study at Maitara Village, North Tidore District),"Journal of Government of Archipelago,vol. 1 (1), 2020.

[15] Utami, NKPN., Pramesti, IGAA., "The Analysis of Factors Influencing Operational Performance of Credit Unions in the North Denpasar District on Period 2015-2018,"Paulus Journal of Accounting,vol. 2 (1), 2020. 
